\title{
c. $\mathfrak{B}$. Conteffa's

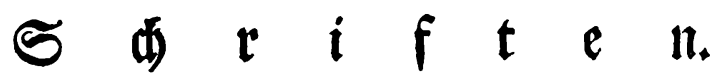

Scerauggegeben

on

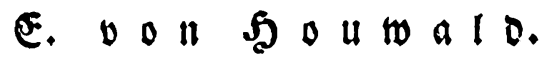

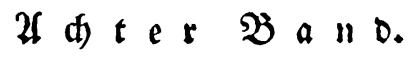

$$
\mathfrak{f} \mathfrak{i} \mathfrak{i} \mathfrak{z} \mathfrak{i} \mathfrak{g},
$$

bei குeorg Joadim B̈마en 1826 . 
